\title{
Dynamic Reflections on Constitutional Justice
}

\author{
Roberto Scarciglia \\ Department of Political and Social Sciences, University of Trieste, Trieste, Italy \\ Email: scarcigliar@sp.units.it
}

Received 5 March 2014; revised 2 April 2014; accepted 26 April 2014

Copyright (C) 2014 by author and Scientific Research Publishing Inc.

This work is licensed under the Creative Commons Attribution International License (CC BY). http://creativecommons.org/licenses/by/4.0/

c) (i) Open Access

\begin{abstract}
This article attempts to propose critical reflections on "historical" models of Constitutional Review. The gradual depletion of the simplified classification system of constitutional review has been identified, by some scholars, as a failure of the bipolar American-European model. This means that it is necessary to rethink the approach to analysing constitutional review, in light of legal traditions, positive law within legal systems, and comparative methodologies. Consequently, judicial review could be studied according to the internal perspectives of the Supreme and Constitutional Courts' decision-making processes, rather than externally observable legal characteristics. As of recently, legal studies have been converging with other sciences, such as cognitive science. They have been considering the relationship between consciousness and comparison, and even the field of cognitive errors in judgment, and the development of decisions taken by Courts.
\end{abstract}

\section{Keywords}

\section{Constitutional Justice, Judicial Opinions, Neuroscience and Law}

\section{Introduction}

The control of the constitutionality of laws is one of the topics discussed in the lectures of comparative constitutional law. Overtime, we have seen a gradual depletion of the simplified system of constitutional reviews. The failure of the American-European bipolarity has highlighted a need to rethink the description of Constitutional Justice Systems, in light of positive laws within different systems and methodologies (Fernández Segado, 2004: p. 1108). In this regard, reference could be made to the overcoming of "historical patterns", in order to show how far models used in teaching and research are inadequate, for a number of reasons detailed below. Mainstream studies on Constitutional Justice tend to primarily identify key factors in the two known historical models subjected to classification according to constitutional doctrine. Despite being undoubtedly useful for compara- 
tive analysis, these elements do not allow the determination of which of these key factors prevail within each constitutional experience. Said factors, which are known as "formants"1, compose and decompose each other, determine the prevalence and influence of a solution adopted by a constitutional court, as well as the manner in which to communicate to the outside world the "strength" of said decision. The "game" of legal formants tends to identify models with heterogeneous characteristics. These are more related to cultural and legal traditions of the respective constitutional system, than to insignificant differences within limited classificatory hypotheses (Harlow, 2002: p. 339). Subsequently, and according to a well-known expression by the American jurist Henry Wigmore, we can talk about the "kaleidoscope" of constitutional justice, to indicate all those factors that can be composed and decomposed, producing different results from a dynamic perspective (Wigmore, 1941). The kaleidoscope of justice contains a table where we can see some of the figures that the rotations of a prism-in fact, that of a kaleidoscope - can be produced starting from common elements. Wigmore had already observed, in $A$ Panorama of the World's Legal System, the importance of images in the knowledge of the law.

Against this background, we support the hypothesis that each model of constitutional justice is different from one another, although two models can describe common characters with American and European historic models. It is the combination of some factors to determine the models- "unique models"-, which could have the name from each State (French, Portuguese) or the geographic area of its origin (Nordic, African, etc.). Between the two sets A and B it is possible to identify an element-in this case, a rule or a procedure or a legal formant that is common to both sets-, which could form part of an intersection of two sets ( $I=A \cap B)$, and which may contain other elements common to A and B. However, according to Rodolfo Sacco, we cannot found, within a legal system, a criterion to determine which is the reciprocal position of legal formants, their consistency of opposition and, therefore, the reasons for their prevalence (Sacco, 2007: p. 119). With regard to unconscious insights, Oliver Wendell Holmes emphasizes "mute" elements, invisible factors that can influence a judge's decision (Holmes Jr., 1897: p. 457). In the first part of the paper, I will deal with the determinants and variables of the models of constitutional review, and how the factors which are characteristic of a constitutional justice system compose and recompose themselves, producing different results from a dynamic point of view.

The second part of this short essay is dedicated to finding a different approach to the traditional point of view which characterizes constitutional justice. This study could not have been carried out in terms of the externally observable legal characteristics, but rather, from the point of view of the Supreme and Constitutional Courts' internal decision-making processes. As of recently, legal studies have converged with scan paths typical of other sciences, including cognitive science. For example, one might consider the relationship between consciousness and comparison, the issue of cognitive errors in judgment, the nature of a court's decisions, or, even, the means to communicate deliberative procedures. In this regard, we can make reference to "cryptotypes", non-verbalized formants that do not belong to the category of positive law. Could these non-verbalized formants influence a judge's decision? This question implies answering many problems that have been studied, or developed in interdisciplinary researches, by several judges of Supreme and Constitutional Courts. These problems may be included in the expression "Law and Brain", used to encompass the study of legal phenomena in light of cognitive science. It is clear that this is a way to simplify a varied and complex set of phenomena. This perspective could become necessary to outline the new frontiers of comparative law, as Rodolfo Sacco points out in his Antropologia giuridica (Sacco, 2007).

Thus, if examined from a different point of view, the deliberative process followed by Supreme and Constitutional Courts suggests a number of questions, such as: how do judges of Supreme and Constitutional Courts think? How do judges take their decisions? How do Courts communicate? From a methodological point of view, together with the theory of legal formants by Rodolfo Sacco and the rules which Costantinesco introduced for obtaining an understanding of the comparative method (Constantinesco, 1972: p. 161), one can highlight how methods of interpretation are always those belonging to the place where a court interprets the Constitution. This depends on a set of Constitutional factors - such as the type of state or government, extra-constitutional factors—-such as cultural and legal traditions, or political, social, economic and religious factors (Fernández Segado, 2004: p. 1108). In this regard, one can recall the books by Patrick Glenn, Legal Traditions of the World (Glenn,

\footnotetext{
${ }^{1}$ The term "formant" is used in phonetics to define the acoustic spectrum of a vowel sound. It is a well-known legal concept in comparative law which indicates the set of rules and propositions of law that are the basis for the solution of a problem or the discipline of an institution or a legal phenomenon in a system at a legal and historical moment: see Sacco, R. (1974), Les buts et les méthodes de la comparaison du droit, IX Congrès International de Droit Comparé, Milano: Giuffrè, 119. The theory of formants is wide-spread among comparatists in common law largely due to the English translation of the study in question: see Sacco R. (1991), Legal Formants: A Dynamic Approach to Comparative Law, American Journal Comparative Law instal 1, 1, and instal 2, 343.
} 
2007) and Werner Menski, Comparative Law in a Global Context (Menski, 2007) which opened entirely different perspectives for studies focusing on the dichotomy between civil and common law. However, with regards to the initial problem, one can see how the classification of constitutional law is made by comparatists, does not seem to always take into account the above-mentioned factors and theories regarding determinative elements and legal formants.

\section{Determinants and Variables}

Firstly, let us go over the concept of determinant or primary element, defined as "simple parts of a chair" in Wittgenstein's Philosophical Investigations (Wittgenstein, 1953: p. 34). This concept could be useful in the identification of differing patterns or experiences in relation to the legal and cultural tradition within a constitutional system, rather than limited by classification schemes. Thus, considering that, though with significant differences, almost every country in the world has at some point instituted a judge to take decisions regarding the constitutionality of laws, what can be considered as essential elements in the kaleidoscope of constitutional review? With regards to the "kaleidoscope of justice", designed in 1941 by Henry Wigmore, one can observe a variety of images (Europe, Asia, America, Africa, Oceania, the Ancient World and a basic model) (Wigmore, 1941). Each one of them is composed by two invariant figures, the kite and the arrow ${ }^{2}$.

This example can turn out useful to look for within a system of constitutional justice elements that do not vary structurally in the time. The first invariable one is without a doubt the presence of an organ (o) that exerts the constitutionality control, whether is an ad hoc court or an organ of the jurisdiction (or its specific section) placed in the peak of the system of the justice of a country (for instance a Supreme court). On this necessary element some variables can be added: a) the chronological moment of control (c), which could be preventive ( $c^{1}$ ) or successive $\left(c^{2}\right)$, according to whether it is exerted before the normative act is approved definitively by the legislative organ, or after the implementation of the act; b) the control's abstractness (a) or concreteness $\left(a^{1}\right)$, depending on whether it is carried out without a judge's guidance, or roots in a judicial procedure in which the judge must apply legal norms in the actual case or controversy; c) admittance procedures to constitutional justice (p): these vary according to whether they can be directly $\left(\mathrm{p}^{1}\right)$ or indirectly $\left(\mathrm{p}^{2}\right)$ admitted; d) the modalities of appointment or designation of judges (n) — which can be determined by a major or minor dependency on political power, and the composition of the court $(t)\left(t^{3}, t^{4}, t^{5}, t^{7}, t^{8}, \ldots . t^{n}\right)$; and, finally, e) the duration of appointment (d), which can be limited in time $\left(\mathrm{d}^{3}, \mathrm{~d}^{4}, \mathrm{~d}^{5},[\ldots] \mathrm{d}^{7}, \mathrm{t}^{8}, \ldots \mathrm{d}^{\mathrm{n}}\right)$, or be for life $\left(\mathrm{d}^{\mathrm{x}}\right)$, such as in the United States. Another invariable is the judgement that the constitutional judge passes (J). In this regard, there is a difference, as, for example, in the Italian experience, between judgments and orders. Orders are procedural decisions and cannot close a case. Judgments, on the other hand, can be: a) of acceptance $\left(\mathrm{j}^{1}\right)$ or of dismissal $\left(\mathrm{j}^{2}\right)$, meaning that the Court either: accepts, even if only partially, the petition of unconstitutionality; or, dismisses the claim.The decision between a judgment of admittance and one of dismissal can be considered as lacking in the identification of a system of constitutional review. Constitutional Courts introduced new types of judgment (i.e. additive, interpretative - of acceptance or of dismissal-, manipulative, substitutive, etc.), in the implementation of instruments of constitutional justice: $b)$ typical ( $t$ ) or atypical $(t-x, t+x)$, according to whether the judgment can be included in a previous pattern; c) the parties bound by a judgment (b), by the difference between a centralized $\left(b^{1}\right)$ or widespread $\left(b^{2}\right)$ model of constitutional review. All of the above mentioned variables are of significant value. It is up to those who will interpret them, to analyze these variables in different legal systems, and compare them to different foreign rules, through the use of interpretive criteria and procedures. There is no greater mistake than a legal interpretation of a foreign law through the eyes of a "conservative lawyer", as this may lead to significant errors, such as those made by Law ethnologists when studying the institutions of ancient populations through contemporary eyes. The letters that identify determinant elements $(\mathrm{O}, \mathrm{J})$, and variables $\left(\mathrm{c}, \mathrm{c}^{1}, \mathrm{c}^{2}, \mathrm{a}\right.$, $a^{1}, p, p^{1}, p^{2}, t, t^{3}, t^{4}, t^{5}, t^{7}, t^{8}, \ldots . t^{n}, d, d^{3}, d^{4}, d^{5},[\ldots] d^{7}, t^{8}, \ldots d^{n}, d^{x}$, etc.), may encourage one to use them in a geographic map or atlas of comparative constitutional law, as in Wigmore's Panorama of the World's Legal Systems (Wigmore, 1936). With regards to the mathematical theory of sets, a brief remark should be made. Each set, which could be equivalent to a foreign experience of constitutional review, can contain variables and determinant elements that could bring about the convergence of two or more sets. This does not exclude, however, that one or more legal systems may not contain (or only marginally contain) common elements: sets have different characteristics, as opposed to the well-known classification schemes.

\footnotetext{
${ }^{2}$ The kite and the arrow also inspired the creation of the British mathematician, Penrose, known as "Penrose tiling".
} 


\section{Inadequacy of "Historic Models"}

The term "model" implies by itself and the idea of classification, of a synthesis of the complexity through logical categories. The classification implies the definition by categories (or classes) of the objects of analysis, through the detection of peculiar traits of all the objects that can be traced back to that class. Although the idea of defining models and classification schemes represents a constant in several papers, no doubt, it does not seem likely apart from an assessment of the ability of these models to understand and reproduce the phenomenon which we believe, and, above all, implement it effectively in a concrete experience (Badiou, 1969). The originally developed models of constitutionality—-the "American" of judicial review, and the "European”, created by Hans Kelsen-summarize of the main issues in the field of Constitutional justice (Tusseau, 2009: 17). Without a doubt, the usual descriptions seem to be limited when we switch from the perspective of the classificatory hypothesis to a methodological approach that characterizes a valid comparison. The presence of some considerable classifications and models-arisen in the shade from both more well-known and traditional icons of constitutional judicial review-, it is particularly useful for the study of the activity of the judge of the laws and forms a dogmatic basis for the overcoming of the traditional typologies and the classification of others which we cannot be considered within the American or European model. Nevertheless, the typical and determinant elements of the "bipolar" model do not allow using its conceptual schemes like classification instruments and the doctrine tried to outline new models, through the "hybridisation" of these historic models.

The factors which are characteristic of a Constitutional justice system-like pieces of a kaleidoscope-compose and recompose themselves, producing different results from a dynamic point of view. The common matrices establish themselves according to individual and changing directions, sometimes oriented towards the defense of fundamental freedoms, sometimes to the balance of power, and the different organs of the State, highlighting the difficulties for comparatist to describe a system of Constitutional justice in accordance with theoretical categories. The common matrices establish themselves according to individual and changing directions, sometimes oriented towards the defense of fundamental freedoms, sometimes to the balance of power, and the different organs of the State, highlighting the difficulties for a comparativist to describe a system of constitutional justice in accordance with theoretical categories.

The reduction of these models can be taken into account for various reasons. The presence of common elements, or a theoretical creation of macro-models of Constitutional review, does not exclude the existence of some unique models. In spite of a standardization of the functions of the organs of Constitutional justice, we cannot except that the combination of different factors brings about incomparable models. Otherwise, the problem of finding the determinants is typical of all empiricalscience. As Quine argues, although with reference to linguistic forms, not at all two situations are quite similar: He argues: "The only difference between rabbits, undetached rabbit parts, and rabbit stages is in their individuation. If you take the total scattered portion of the spatiotemporal world that is made up of the rabbits, and that which is made up of undetached rabbit parts, and that which is made up of rabbit stages, you come out with the same scattered portion of the world each of the three times. The only difference is in how you slice it” (Quine, 1969: 32).

From this point of view, it is necessary, on the one hand, grasp similarities in material aspects and, on the other, do not lose sight of the basic constituent parts that make up an object (of study) (Quine, 1953: 82).

The procedure of decomposition of formants is a complex operation and not used by the legal practitioner who is unaccustomed to comparison. Formants have a tendency to combine as well as to de-compose within a certain law. This decomposition happens synchronically and it is up to the comparatist to assert whether these disassociations happen in a predictable and rationally explainable way. With reference to the doctrine of Public Law, it was noted that the components of the legal system are not on the same level $\left(F \neq F^{1}, F^{1} \neq F^{2}\right)$, resulting in one being elevated to "the category of comparison", and given prevalence $\left(F>F^{1}, F^{1}>F^{2}\right)$. A system of constitutional justice represents a subsystem in the context of the legal system of a certain country, analogous to which it happens in the theory of the sets between "set" and "element". If the system of constitutional justice z-element $\mathrm{z}$ belongs to Country $\mathrm{Z}$ - the joint $\mathrm{z}(\mathrm{z} \in \mathrm{Z})$, that does not mean that the elements of the system of Constitutional justice of Country A ( $g, g^{1}, g^{2}$ - - that belong evidently to Country A ( $\left.g, g^{1}, g^{2} \in A\right)$ —would have to be equal or equivalent to those of Country $\mathrm{Z}\left(\left\{\mathrm{g}, \mathrm{g}^{1}, \mathrm{~g}^{2}\right\}=\left\{\mathrm{z}, \mathrm{z}^{1}, \mathrm{z}^{2}\right\}\right)$. It is more probable that only some of these elements agree and must be, in each case, interpreted according to the interpretative method of the own legal system. We point out that each legal system can own valid contents in other legal systems. For instance, in connection with the Constitutional review, if a system $\mathrm{Y}$ integrates statements $\mathrm{x}^{1}$ and $\mathrm{x}^{2}$, coming from system $\mathrm{X}$, 
and statements $\mathrm{z}^{1}$ and $\mathrm{z}^{2}$, coming from system $\mathrm{Z}$, those same statements $\left(\mathrm{x}^{1}, \mathrm{x}^{2}, \mathrm{z}^{1}\right.$ and $\left.\mathrm{z}^{2}\right)$, are valid insofar as $\mathrm{xs}^{1}, \mathrm{xs}^{2}, \mathrm{z}$ have been integrated in the system $\mathrm{Y}$. Until this integration does not take place, the statements $\mathrm{x}^{1}, \mathrm{x}^{2}$, $z^{1}$ and $z^{2}$ do not belong to the set $Y$, and they are not valid. Afterwards, these elements may be part of the set $Y$ $\left(x^{1}, x^{2} \in Y\right)$ if the same elements turn into rules of the legal system in which the elements can integrate. The rules of this integration can show a high level of complexity. That points out that some elements or (legal) formants, in its process of composition or decomposition, can bring about a unique result, like after the rotation of a kaleidoscope. If we consider a number of determinant elements or verbalized (or not verbalized) legal formants existing within a legal system, it seems more consistent to refer to different systems of Constitutional review (e.g. Belgian system of Constitutional justice) or to specific geographical areas (e.g. North America). From this point of view, our analysis could be better than to include this experience in a "turnkey system". Moreover, an analysis carried out $a b$ externo does not allow evaluating which are the deliberative paths for a definition of judgment. Above all, this analysis cannot pick out the presence or role of extralegal factors in the decision of a Court or a judge (decision-making strategies of individuals). Thus, the study of comparative constitutional justice is carried out, principally, from point of view of legal characteristics outside the observable, through the study of the decisions of the Constitutional or Supreme Courts. We have to point out that some studies coming from other sciences-including cognitive-give essential elements for analyzing the internal deliberative process by the Courts. In the recent years, the field of the relationship between the law—and, particularly, comparative law-and other sciences is growing. This tendency increases some cognitive approaches-law in mindwhich aim to overcome the traditional dichotomy between "law in the books" and "law in action" (Chorvat \& Mc Gabe, 2004: 1733). The objective is not so much knowledge of the law in the books or of the law in action as much as research with its inherent limits of the law in minds of legal systems (Ewald, 1998: 704) that, sometimes allow knowledge that each legal decree is unique and that within it models develop which are unique (Ainsworth, 1996: 28). The same is true for words, whose meanings, according to Croce's aesthetic, assume a unique meaning which is linked to the historical and semantic context where the terms are used. These approaches take into account some late researches about the field of cognitive neuroscience.

\section{Usefulness of Cognitive Science on the Law}

Frequently, cognitive neuroscience deals with phenomena in connection with the law (Garland, 2004; Zeki \& Good enough, 2006; Frankel \& Garland, 2012). Paths of scientific collaboration with legal scholars are active in many fields, such as process, the evaluation of errors of judges and criminal liability. From this point of view, the relationship between neuroscience and law tends to investigate whether the rational choices - with which the courts make their decisions - are influenced by different factors such as, for example, attention, memory, emotion, intuition or moral judgment. These studies are only at an early stage and, accordingly, these reflections have the original intent to induce the attention, as an interdisciplinary field of study, rather than reveal feasible coordinates. Considering the average posting of lawyers for the hard sciences, Erin Ann O'Hara has identified the categories of lawyers who could feel it (O’Hara, 2006: 25). One could think there should be between these include also the comparatist for the necessary traits of contiguity with the other sciences. In the Introduction to 2006's Law and the Brain, Lord Bingham emphasized that a decision can be driven both by reason and emotion, or other factors that may affect them, according to The Path of Law written by the Justice Oliver Wendell Holmes, Jr. and published in Harvard Law Review. Although the writings of Holmes are always present in the debate between the normative and American realist schools, they, however, represent one of the landmarks of the scholars who are concerned with the relationship between neuroscience and the law.

Everyone could remember the theory expressed in The Common Law, 1881, according to which "the life of the law is experience, not logic” (Holmes Jr., 1881). It also reminds us that different factors—such as the shared needs of the time such as the shared needs of the time, the prevalent moral and political theories, the known or tacit political intuitions or the prejudices which judges share with others-contribute to a greater extent in determining the rules of government than the syllogism. The mentioned thought of Holmes has points in common with the subsequent studies on unexpressed knowledge, required to the comparative science. In this respect, before briefly examine the cognitive factors that may affect the choice of a judge-and, therefore, errors, particularly coherent order, in the decision - it may be able to recall the concept of value due to different legal formants. Holmes points out the "unknown" or "mute" formants with reference to the insights and unconscious, therefore, unobserved factors that can affect the judge’s decision. However, according to Rodolfo Sacco, it is not possible 
to identify a criterion, within a legal system, which determines the position of the formants, their coherence in opposition or the reasons for this prevalence.

\section{Toward New Frontiers: How Do Judges of Constitutional and Supreme Courts Their Decisions?}

We acknowledge that this current of studies is still at its early stages, however we believe that for overview purposes, it can be useful to consider the approach put forward so far, by scholars from supreme and constitutional courts. A previously mentioned example is that of How judges think, by Richard Posner, whence I drew my main remarks (Posner, 2008: 66). Valuable observations are also provided by other watchful scholars looking into how judges speak, namely Basil Markesinis and Jörg Fedtke (Markesinis \& Fedtke, 2006: 173). Moreover I believe useful recalling some concepts referred to in the first part of this essay, among others, Michael Polanyi's "tacit knowledge", and thus the tacit dimension of comparison (Polanyi, 1966). Accordingly with the Hungarian philosopher, the accent should go on those latent elements of the judicature that are not immediately detectable — and often can neither be directly integrated — which are inherent to the interpretative and deliberative processes of supreme courts. However these elements do not always result from analyses, motivations, or even from the very own courts' jurisprudential classifications.

This, for instance, could make the considerations on the grounds for the decision seem superfluous, as these represent only the final outcome of a more complex process. From this perspective, it can be interesting to study the modalities by which judges of supreme and constitutional courts take their decisions, within the deliberative process, which still today, is a scarcely studied topic by scholars of the so-called deliberative democracy, despite these courts being considered deliberative institutions.

Further classifications were also conducted in relation to the object of the investigation, from the standpoint of those plaintiffs entitled to bring an action before the courts, to the collegiality's proceedings methods. The latter profile raised some interest for what concerns the topic of decision-making according to seriatim procedures as well as for decision-making expressing a position of majority or minority, and for when the court is considered a collective subject. These diverse perspectives of analysis, which now cannot be extensively discussed, do however cast a light on scholars' interest on the broad topic addressing the process, the modality and the factors by which courts take their decisions.

One could observe that different factors can or help to determine the decision of a judge. Besides personal factors, Posner describes five "phenomena" which can be included in this question: a) conscious falsification; b) precedents determined by experience, temperament, ideology and other extra-legal personal factors; c) cognitive illusions; d) precedents determined by irrelevant reactions; e) distortion of facts to limit the probabilities of being overturned.

As far as conscious falsification is concerned, this is a residual hypothesis, whereby we consider the impartiality of judges when performing their duty, a constitutional principle as stated by founding documents and by the law. However, if for instance, the judge were to have been corrupted, the incidence of such behaviour on the final decision would be obvious: the judge would have indeed consciously followed the "rule of the bandit"de-formant-falsifying the essence of the grounds for the decision, without, maybe, leaving any trace unless a further trial were to unveil the falsification itself.

For the second hypothesis, Posner takes into consideration the precedents determined by experience, temperament, ideology and other extra-legal personal factors. Going back to what was said regarding legal formants; for these factors too, it is difficult to defining a priori what would be their mutual position, their coherence of objection and whether they would prevail. Certainly for a comparativist, these factors and their use in foreign legal systems, immediately bring to mind the scarcely investigated topic of judges' mentality (Markesinis \& Fedtke, 2006: 173). As mere example, one could think back at the behaviour of the judge who refused to include ideas from a foreign country during the decision-making process, as it happened with judge Scalia for the sentence of the American Supreme Court for Roper v Simmons in 2005.

According to Markesinis, mentality is "an inhibiting factor, or the most important factor, within the use of comparativism", but more in general, he states that "the role played by mentality has not been appropriately studied, and as a result its importance has been underestimated” (Markesinis \& Fedtke, 2006: 174). As observed by the judge of the Supreme Court Felix Frankfurter, a man [or a woman] "when sitting in the Supreme Court takes with him his entire experience, training and prospects as well as personal social, intellectual and cultural 
backgrounds”. Personal factors could determine the so-called puzzling effect in the jurisprudential procedure, however this cannot be ascribed solely to these components but to the contribution of a number of factors. Nonetheless, according to Markesins the possibility for a connection "in a definitive way between sentences and individual personality traits” (Markesinis \& Fedtke, 2006: 174) should be ruled out, together with the feasibility for a study of these factors, starting from the professional training of judges.

The third factor is given by the so-called cognitive illusions. These derive from a mistaken perception of reality. For instance, when observing any given object, it could happen that some of its parts may not be perceived by the observer. Indeed, even if he/she were to see them, on a perception level, these parts could suddenly stand out, or not stand out, limiting perception itself. An example is provided by the renowned image of Jastrow, also used by Wittgenstein, where looking from the right one sees the head of a hare, whereas looking from the left one sees the head of a duck and there are many other examples of this sort. Moreover a judge can make such mistakes when in peculiar conditions, provoking cognitive illusions (Guthrie, Rachlinski, \& Wistrich, 2001: 7) by repeating such errors, and the same may happen to juries during trials (Markesinis \& Fedtke, 2006: 174). In the aforementioned essay Inside the Judicial Mind, the analysis focuses on which mechanisms can be useful to minimize the effect of cognitive illusions, as for example the so-called Hindsight Bias, which is the error committed in a retrospective judgement.

A further hypothesis which is also to be considered residual, as it is not very frequent in a Supreme Court's decisions, is that of precedents determined by irrelevant reactions, as could happen if a decision were to be determined, for instance, by a personal dislike for a conduct of life or even for the disapproval of a religious party. The reason for the narrowness of this hypothesis lays in the fact that similarly to the aforementioned case a), the deliberate falsification of facts is not common, and in general, a judge should not be involved with disputes involving parties, religions and any other kind of association.

The last hypothesis put forward by Posner is that of the distortion of facts to limit the probabilities of being overturned, wherefore according to Bayes' theory of decision the main feature of the decision is that of leaving the precedent unaltered. In these hypotheses the pre-formation of the judge's opinion, developed for previous cases_-and thus already formed at an unconscious level_-determines with high probability that the judge will not modify the precedent, even with the acquisition of new information, according to the equation $\Omega(\mathrm{H} \backslash \mathrm{x})=$ $\mathrm{p}(\mathrm{x} \backslash \mathrm{H}) / \mathrm{p}(\mathrm{x} \backslash \mathrm{H}) \times \Omega(\mathrm{H})$ (Posner, 2008: 66), whereby Bayes proves how, despite the acquisition of new information, the probabilities (of modifying the precedent) do not change.

\section{The Judge as "Occasional Legislator"}

The expression “occasional legislator” comes from the book of Richard Posner, How Judges Think (Posner, 2008: 66), and it indicates the intention-expressed in the Swiss Civil Code_-, according to which "were the law is silent or unclear the judge must decide the case as if he were a legislator". As we point out, in some legal systems (European or Latin American systems) the courts increased the number of instruments for exercising constitutional review. As an example, the court can "manipulate" the contents of the law which is the subject of the Constitutional Court's judgment, transforming its original meaning (e.g. in the "substitute judgments”). The courts can manipulate normative texts, not only judging the dispositions (that is the semantic statements contained in a text), but the norms (the meaning derived by interpretative route of the statements) and, consequently, not only annulling, but also modifying the opposed dispositions to ensure the conformity the deductible norms of them to the constitutional parameters. The use of manipulative techniques tends to affect the discretion of the legislator in law-making and, therefore, a part of the constitutional doctrine calls into question its admissibility. It could turn out useful better explain the purpose of the "substitute judgments"_-judgments which include a new, literal, text in substitution of a part of the text of a law-by a constitutional court, if we use the concept of Kelsen's “interference”. This concept expresses the qualification (Ermäcthigung) that a legal system attributes to a constitutional organ for the production of legal norms, also determining its conditions of validity.

The interferences can be distinguished into two types: compulsory or not (Behrendt, 2006: 126). The interference $(I)$ constitutes a kind of qualification $(Q)$ - which could affect so either the legislator $(Q L)$ or a constitutional court $(Q C C)$ — for the production of a certain type of norms $(N)$ and, particularly, legal norms $(L N)$. The interference can be expressed as a formula in the following way: $I=Q \rightarrow L N$. The interference could affect a constitutional (or a supreme) court, if the same court introduces necessary and sufficient conditions ( $C 1$, $C 2$, $\mathrm{C} 3, \ldots \mathrm{Cn}$ ) for the validity of the norms that can be produced by virtue of the qualification. We can express it as 
a formula in the following way: $Q L(C 1, C 2, C 3, \ldots C n) \rightarrow L N=(Q C C)(C 1, C 2, C 3, \ldots C n) \rightarrow N L$. According to the pattern by Behrendt, the constitutional court could allow for different possible conditions, in the sense that the validity of the norm cannot already set down with respect to a necessary condition $(C 1, C 2, C 3, \ldots C n)$, but, on the contrary, it has caused by a choice between two alternatives (e.g. $C 2 a$ v. $C 2 b$ ). This alternative can be expressed by this formula: $Q(C 1, C 2 a$ v. $C 2 b, C 3, \ldots C n) \rightarrow L N$. In the event that there are necessary conditions, we are in the presence of a certain interference; on the contrary, we can speak of an alternative interference if we are in the presence of two or more alternatives.

By means of the use of manipulative techniques, the judge tends to affect the choice of the legislator, considering itself "qualified" for the creation of a norm, even "through other channels, not always immediately apparent in all their growth and consistency": it happens in the hypothesis of a masked violation of a Constitutional parameter or a substantial rewrite of the letter of the Constitution, through the terms of the grounds in the ruling of the Court. Against the observation that the Constitutional judge could in this way encroach upon the jurisdiction which the Constitution reserves for the legislator, it would be possible to object that the Constitution attributes to the constitutional organs the power of amendment, for example, by a new legislative measures.

\section{How Do Courts Communicate?}

How do constitutional and supreme courts communicate? This question regards the way in which judges convey their views and opinions to citizens and to other constitutional bodies, and it may well contribute comparative takes to the current debate concerning divulged opinions on the one hand, and secrecy within courts on the other (Cassese, 2013). Resuming the discourse on the factors that affect a judge's decision at the cognitive level, one can observe how the disclosing of the opinions also includes subjective elements, which, together with other factors, contribute to a judge's grounds for the decision. Sabino Cassese, in reference to the so-called dissenting opinion, asked himself whether "one of the variables to be taken into account, in order to assess the introduction of dissent, might be the extent of social adhesion to constitutional values and the degree of the rift within the public opinion".

The latter approach is important when considering the relation between courts when it comes to the not necessarily oracular communication with other constitutional bodies. Also in the case of the so-called oral dissenting, with which the Justices of the US Supreme Court promulgate verbally an opinion contrary to a majority decision of the Court, one can identify several factors which contribute to its induction, according to the analysis put forward by Schmidt and Shapiro (Schmidt \& Shapiro, 2010: 75): a) personal angst towards the Court (Gold Clause Case-Justice McReynolds, 1935); b) publicity of own decisions (Gold Clause Case-Justice McReynolds, 1935); c) public appeal to citizens (Pollock Case-Justice Arlan, 1895); d) commitment to the Constitution (Gold Clause Case-Justice McReynolds, 1935); e) the so-called demosprudence, i.e. popular education; f) appeal to the elites; g) democratic responsibility.

Concerning the term demosprudence (with reference to demosprudential oral dissent), coined by Lani Guiner and Gerald Torres (Guiner, 2008: 4; Torres, 2007: 135), we may tautly emphasize that the main manifest function of dissent appears to be that of re-orienting public opinion: a pedagogical function that, as regarded by Justice Kennedy, portrays judges as teachers who, through their opinions, educate. Nevertheless, at an operational level we may consider US citizens quite unaware of the Supreme Court's activity; for instance, citizens interviewed at the time had little or no knowledge, despite the significance of the issue, of the Roe vs. Wade case examined by the Court in 1973, regarding abortion during the first three weeks of pregnancy. Hence, the idea that US citizens may be informed through oral dissenting is likely to be purely wishful thinking. Also in this perspective, at the cognitive level it should be appreciated how the study of the cultural background and professional training of a judge may contribute to this point in question, as well as the judge's own decision within the court, and whether he may have been influenced by, or might have in turn influenced, the decision or the college itself. Consequently, as pointed out by Cassese, it is "the way in which the will of the court is established that influences the structure of the decision, and therefore also the way in which the judge's opinion is presented" (Cassese, 2013).

\section{Conclusion}

Comparing the shaping of the supreme and constitutional courts' will well be an increasingly attractive perspective with regards to the traditional classification of historical models of constitutional justice. The gradual de- 
pletion of this classification system has been identified, by some scholars, as a failure of the bipolar AmericanEuropean model. Each model of constitutional justice is different from one another, although two models can describe common characters with American and European historic models. This means that we can rethink the approach to analysing constitutional review, in light of legal traditions, positive law within legal systems, and comparative methodologies. Consequently, judicial review could be studied according to the internal perspectives of the Supreme and Constitutional Courts' decision-making processes, rather than externally observable legal characteristics. We should go on those latent elements of the judgements that are not immediately detectable - and often can neither be directly integrated — which are inherent to the interpretative and deliberative processes of supreme courts. However these elements do not always result from analyses, motivations, or even from the very own courts' jurisprudential classifications. As of recently, legal studies have been converging with other sciences, such as cognitive science. They have been considering the relationship between consciousness and comparison, and even the field of cognitive errors in judgement, and the development of decisions taken by Courts. This, together with cognitive sciences, may aid us to progressively identify with increasing clarity the differences in cultural and legal traditions, as well as the uniqueness of said models. The above being a de iure condendo reflection, we should just hope that the establishment of a new cognitive approach to the subject of constitutional justice will find more benevolent interlocutors.

\section{References}

Ainsworth, I. E. (1996). Categories and Culture: On the "Rectification of Names" in Comparative Law. Cornell Law Revue, 82, 28.

Badiou, A. (1969). Le concept de modèle. Introduction à une épistemologie matérialiste des mathématiques. Paris: Fayard.

Behrendt, C. (2006). Le juge constitutionnel, un législateur-cadre positif. Bruxelles: 126.

Cassese, S. (2013). Lezione sulla cosiddetta opinione dissenziente. 1-17.

www.cortecostituzionale.it/documenti/convegni_seminari/Opinione_dissenziente_Cassese.pdf

Chorvat, T., \& Mc Gabe, K. (2004). The Brain and the Law. 359 Philosophical Transactions of the Royal Society, 1733.

Constantinesco, L.-J. (1972). Il metodo comparativo. Torino: Giappichelli, It. tr, 2000, 161.

Ewald, W. (1998). The Jurisprudencial Approach to Comparative Law: A Field Guide to Rats. 46 American Journal of Comparative Law, 704.

Fernández Segado, F. (2004). La faillite de la bipolarité “modèle américain-modèle européen” en tant que critère analytique du contrôle de la constitutionnalité et la recherche d'une nouvelle typologie explicative. In Mélanges en l'honneur de Franck Moderne (p. 1108). Paris: Dalloz.

Glenn, H. P. (2007). Legal Traditions of the World: Sustainable Diversity in Law (3rd ed.). Oxford: OUP.

Guiner L. (2008). Foreword: Demosprudence through Dissent. Harvard Law Review, 22, 4.

Guthrie, C., Rachlinski, J. J., \& Wistrich, A. J. (2001). Inside the Judicial Mind. Cornell Law Review, 86, 778.

Harlow, C. (2002). Voice of Difference in a Plural Community. American Journal of Comparative Law, 2, 339-367. http://dx.doi.org/10.2307/840824

Holmes Jr., W. O. (1881). The Common Law. Boston, Mass: Little, Brown.

Holmes Jr., W. O. (1897). The Path of Law. Harvard Law Review, 10, 457.

Markesinis, B., \& Fedtke, J. (2006). Judicial Recourse to Foreign Law: A New Source of Inspiration. New York: Routledge, 173.

Menski, W. (2006). Comparative Law in a Global Context; The legal Systems of Asia and Africa (2nd ed.). Cambridge: CUP. http://dx.doi.org/10.1017/CBO9780511606687

O’Hara, E. A. (2006). How Neuroscience Might Advance the Law. In S. Zeki, \& O. Goodenough (Eds.), Law and the Brain (p. 25). Oxford: OUP.

Polanyi, M. (1966). The Tacit Dimension. New York: Anchor Book.

Posner, R. A. (2008). How Judges Think. Cambridge, MA: Harvard University Press.

Quine, W. O. (1969). Ontological Relativity \& Other Essays. New York: Columbia University Press, 32.

Quine, W. O. (1953). From a Logical Point of View: Nine Logico-Philosophical Essays. Cambridge, MA: Harvard University Press, 82.

Sacco, R. (2007). Antropologia giuridica: Contributo a una macrostoria del diritto (Legal Anthropology: A Contribution to 
the Macro-History of Law). Bologna: Il Mulino.

Schmidt, C. W., \& Shapiro, C. (2010). Oral dissenting in Supreme Court. William \& Mary Bill of Rights, $19,75$.

Torres, G. (2007). Legal Change: The Eighty-Third Cleveland-Marshall Fund Visiting Scholar Lecture. Cleveland St. Law Review, 55, 135.

Tusseau, G. (2009). Contre les “modèles” de justice constitutionnelle: Essai de critique méthodologique. Bologna: Bononia University Press, 17.

Wigmore, J. H. (1941). A Kaleidoscope of Justice Containing Authentic Accounts of Trial Scenes from All Times and Climes. Washington DC: Washington Law Books.

Wigmore, J. H. (1936). Panorama of the World's Legal Systems. Washington DC: Washington Law Books.

Wittgenstein, L. (1953). Philosophische Untersuchungen . Oxford: Basil Blackwell, 34. 
Scientific Research Publishing (SCIRP) is one of the largest Open Access journal publishers. It is currently publishing more than 200 open access, online, peer-reviewed journals covering a wide range of academic disciplines. SCIRP serves the worldwide academic communities and contributes to the progress and application of science with its publication.

Other selected journals from SCIRP are listed as below. Submit your manuscript to us via either submit@scirp.org or Online Submission Portal.
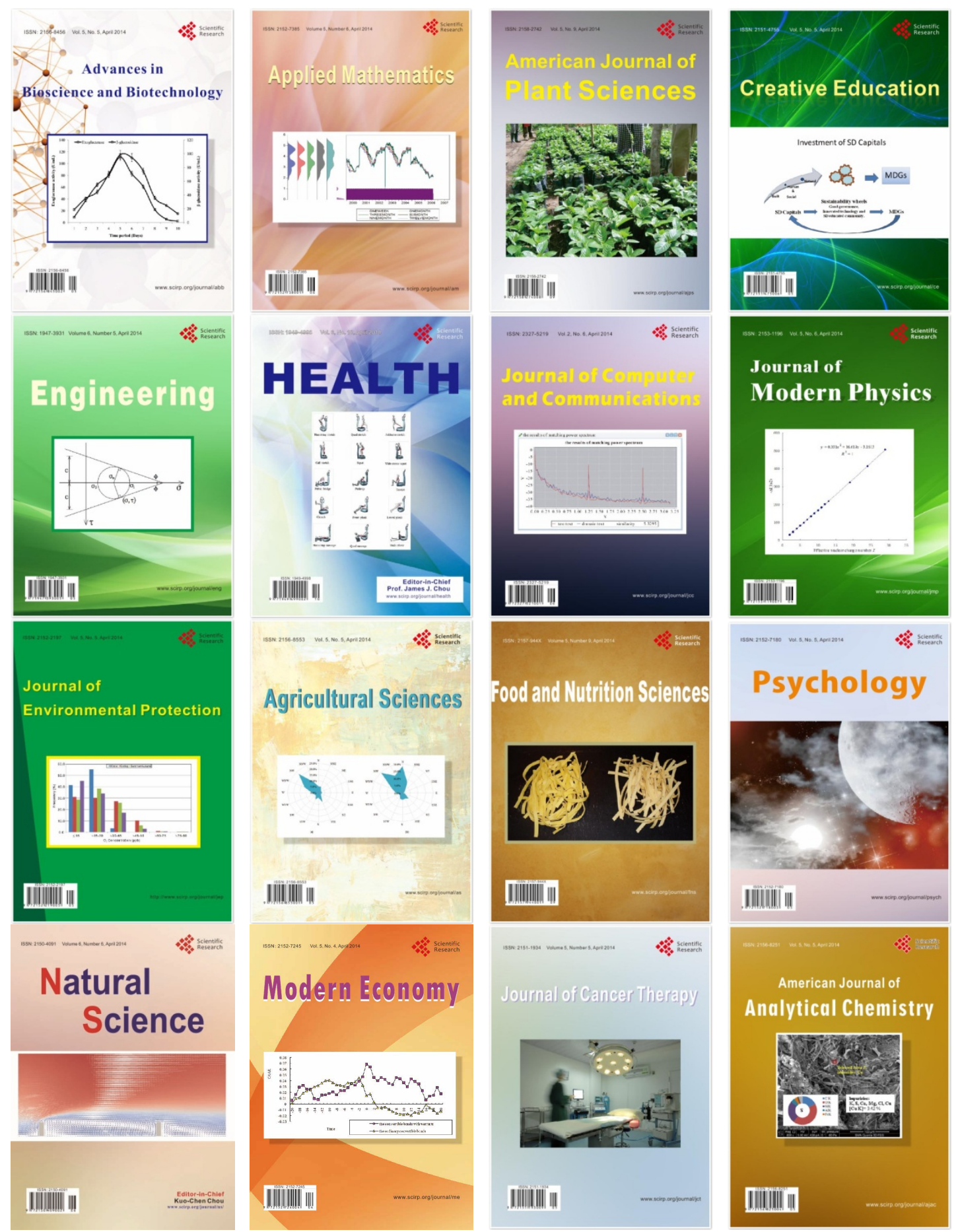